\title{
Gorlin Syndrome in Eleven Patients
}

\section{On Bir Hastada Gorlin Sendromu}

\author{
Gülen Eda Utine, Yasemin Alanay, Dilek Aktaş, Koray Boduroğlu, Mehmet Alikaşifoğlu, Ergül Tunçbilek \\ Hacettepe University Faculty of Medicine, Department of Pediatrics, Division of Pediatric Genetics, Ankara, Turkey
}

\begin{abstract}
Aim: Gorlin syndrome is an autosomal dominant disorder characterized by cutaneous basal cell carcinomas, odontogenic keratocysts and skeletal anomalies. Predisposition to certain types of cancers is among the main features of the disease. Chromosome instability was suspected as a mechanism for cancer predisposition. However, previous studies failed to prove the presence of chromosome instability.

Materials and Methods: We present 11 patients with Gorlin syndrome. Results: Six of the patients were checked for increased sister chromatid exchange and were found normal. Two other patients had concurrent chromosome anomalies.

Conclusion: Evidence for chromosome instability was not found in our patients. Occurrence of chromosome instability in a subgroup of patients and mechanisms underlying cancer predisposition requires further studies for full elucidation. Hairy patches and pigmentary skin lesions are among the recently defined common features of the syndrome.

Keywords: Gorlin syndrome, hairy patch, chromosome instability, sister chromatid exchange, hypopigmented lesion
\end{abstract}

ÖZ

Amaç: Gorlin sendromu kutanöz bazal hücreli karsinomlar, odontojenik keratokistler ve iskelet anomalileriyle karakterize otozomal dominant bir sendromdur. Bazı kanser tiplerine yatkınlık hastalığın başlıca özelliklerindendir. Kromozom kırıklarına yatkınlık kanser yatkınlığı için öne sürülen mekanizmadır, ancak daha önceki çalışmalarda kromozom kııklarına yatkınlık varlığı kanıtlanamamıştır.

Gereç ve Yöntemler: Bu yazıda Gorlin sendromu tanısıyla izlenen 11 hastanın klinik bulguları sunulmuştur.

Bulgular: Bu hastalardan altısında artmış kardeş kromatid değişimi izlenmemiştir. Iki hastada eş zamanlı kromozom anomalileri bulunmuştur. Sonuç: Gorlin sendromlu hastalarda kromozom kırıklarına dair yeterli kanıt bu çalışmada gösterilememiştir ve bunun için daha çok olgu incelenmelidir. Saçı ıamalar ve pigmenter deri lezyonları hastalığın yeni tanınan sık bulguları arasındadır.

Anahtar Kelimeler: Gorlin sendromu, saçlı yama, kromozom kırıklarına yatkınlık, kardeş kromatid değişimi, hipopigmente lezyon

\section{Introduction}

Gorlin syndrome or nevoid basal cell carcinoma syndrome is an autosomal dominant disorder in which multiple basal cell carcinomas, odontogenic keratocysts, skeletal malformations, and soft tissue calcifications are seen (1). Initial description in 1960 included a triad of multiple basal cell nevi, keratocysts in the jaw and skeletal anomalies (2). However, a variety of other manifestations involving ocular, cranial and genital systems are now known to be parts of the clinical presentation.
The syndrome is a cancer-prone condition which may predispose to, besides basal cell carcinomas of the skin, malignant or benign tumors like medulloblastoma, uterine and ovarian fibromas/fibrosarcomas, meningioma and cardiac fibromas (3). Chromosomal instability was suspected as one of the pathogenetic mechanisms of the cancer predisposition in Gorlin syndrome but this was not proven. Chromosome anomalies were rarely reported in patients with nevoid basal cell carcinoma syndrome, which included deletions of chromosome $9 q$ in a few patients (4-7), where the causative

Address for Correspondence/Yazıșma Adresi

Gülen Eda Utine MD, Hacettepe University Faculty of Medicine, Department of Pediatrics, Division of Pediatric Genetics, Ankara, Turkey

Phone: +903123115522 E-mail: geutine@hacettepe.edu.tr

Received/Geliş tarihi: 03.02.2017 Accepted/Kabul tarihi: 20.03.2017

๑๑ Copyright 2017 by Ege University and Ege Children's Foundation

The Journal of Pediatric Research, published by Galenos Yayınevi. 
gene PTCH was later localized. This gene is a multifunctional developmental gene, it functions both in body patterning via Hedgehog signalling pathway, and also as a tumor suppressor gene (3). Sporadic mutations in PTCH gene were also associated with sporadic basal cell carcinomas in 1997 (8).

Herein we report on a series of 11 patients with Gorlin syndrome, in the order of admittance to our department. Six were checked for increased sister chromatid exchange with ultraviolet (UV) exposure and they were all normal. Two others had concurrent chromosome anomalies.

\section{Materials and Methods}

A series of 11 consecutive patients with Gorlin syndrome was retrospectively analysed. A review of clinical features was performed and standard karyotyping procedures were applied. Sister chromatid exchange analysis results were also included where available. The study was approved by Hacettepe University Non-Interventional Clinical Research Ethics Board.

\section{Results}

Clinical and cytogenetic features of the patients are summarised in Table I.

\section{Patient 1}

This female patient had presented at 6.5 years of age with severe headaches. She had a history of late eruption and hypoplasia of teeth. Developmental stages were on time. Physical examination revealed prominent maxilla and mandibula, gingival hypertrophy and absence of teeth. Panoramic X-ray showed a mandibular cystic lesion. Until she was 8 years old, curettage of jaw cysts had been performed three times. Cranial magnetic resonance imaging revealed triventricular widening and aqueductal narrowing. Menstruation had begun at 11 years of age and ceased after two years when hypogonadotropic hypogonadism was diagnosed. Chromosome analysis revealed 46,XX/46,X,t(X;11) (q24;q13). On physical examination at the age of 21 , she weighed $75 \mathrm{~kg}$ and measured $151 \mathrm{~cm}$. She had macrocephaly (head circumference was $52 \mathrm{~cm}$ at 8 years of age), coarse facies with prominent supraorbital ridges and thick eyebrows, ptosis, a flat maxillary region, prognathism and squared mandibula, multiple hyperpigmented lesions on the back (Figure 1a) and below axilla.

\section{Patients 2 and 3}

These two patients were a mother and her daughter. The 31-year-old mother had maxillary and mandibular odontogenic cysts for which she had been operated on three times. Two periorbital lesions were excised and histopathological examination revealed a pigmented basal cell carcinoma and the second was trichoepithelioma. All the cervical vertebrae were deformed and there was cervical scoliosis at the craniocervical junction. Her father had died of skin cancer.

\begin{tabular}{|c|c|c|c|c|c|c|c|c|c|c|c|c|}
\hline Features & Patients & 1 & 2 & 3 & 4 & 5 & 6 & 7 & 8 & 9 & 10 & 11 \\
\hline Age (years) & & 6.5 & 31 & 5 & 19 & 15 & 18 & 47 & 42 & 13 & 17 & 51 \\
\hline $\operatorname{Sex}(F / M)$ & & $\mathrm{F}$ & $\mathrm{F}$ & $\mathrm{F}$ & $\mathrm{M}$ & $M$ & M & $M$ & $M$ & $\mathrm{~F}$ & $M$ & M \\
\hline Odontogenic keratocysts & & + & + & - & + & + & + & + & + & + & + & - \\
\hline Basal cell carcinomas & & - & + & - & - & - & - & + & - & - & - & - \\
\hline Calcification of falx cerebri & & - & - & - & + & - & + & + & - & - & + & - \\
\hline Characteristic facial features & & + & - & + & - & - & + & + & + & + & + & - \\
\hline Head circumference $>97^{\text {th }}$ centile & & + & - & + & - & - & + & + & + & - & + & - \\
\hline Weight or height $>97^{\text {th }}$ centile & & - & - & + & - & - & - & - & - & + & - & - \\
\hline CNS abnormalities & & + & - & + & - & - & + & - & - & - & - & - \\
\hline Palmar or plantar pits & & - & - & - & + & - & - & + & + & + & + & + \\
\hline Hairy patch & & - & - & - & + & - & - & + & + & - & - & + \\
\hline Atrophic or pigmentary skin lesions & & + & - & + & + & + & + & + & + & - & - & - \\
\hline Other tumors & & - & $T$ & - & - & - & - & - & - & - & - & - \\
\hline Teeth hypoplasia or late eruption & & + & - & - & - & - & - & - & - & - & - & - \\
\hline Developmental delay & & + & - & - & - & + & - & - & - & - & - & - \\
\hline Hypogonadotropic hypogonadism & & + & - & - & - & - & - & - & - & - & - & - \\
\hline Extracranial skeletal abnormalities & & - & + & - & - & - & - & - & + & + & - & - \\
\hline Chromosomal abnormalities & & + & $?$ & - & - & + & - & - & - & - & - & - \\
\hline Increased SCEs & & $?$ & $?$ & ? & $?$ & $?$ & - & - & - & - & - & - \\
\hline
\end{tabular}


The 5-year-old daughter had macrocephaly (head circumference was $56 \mathrm{~cm}$ ), coarse facies with frontal bossing, and a café-au-lait spot over the left wrist. Cranial tomography revealed partial agenesis of splenium of the corpus callosum, cerebral atrophy and bilateral frontotemporoparietal subdural effusion. Her karyotype was 46,XX.

a

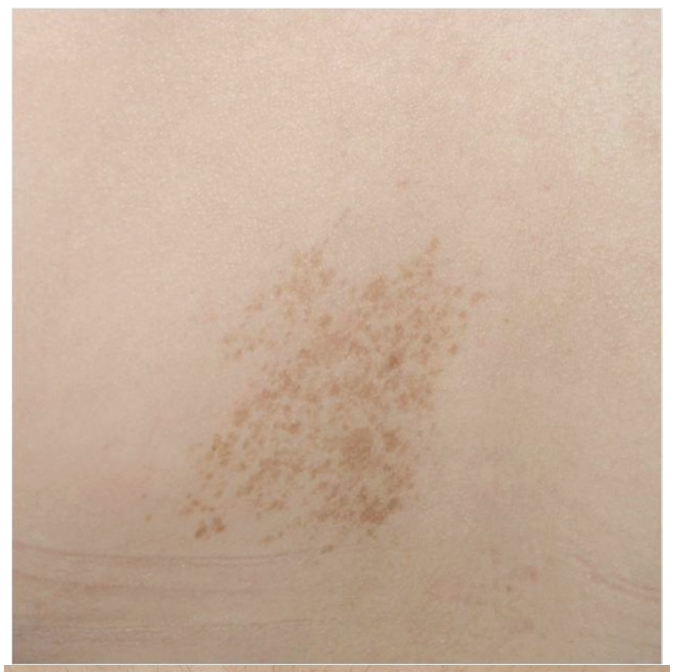

b

C

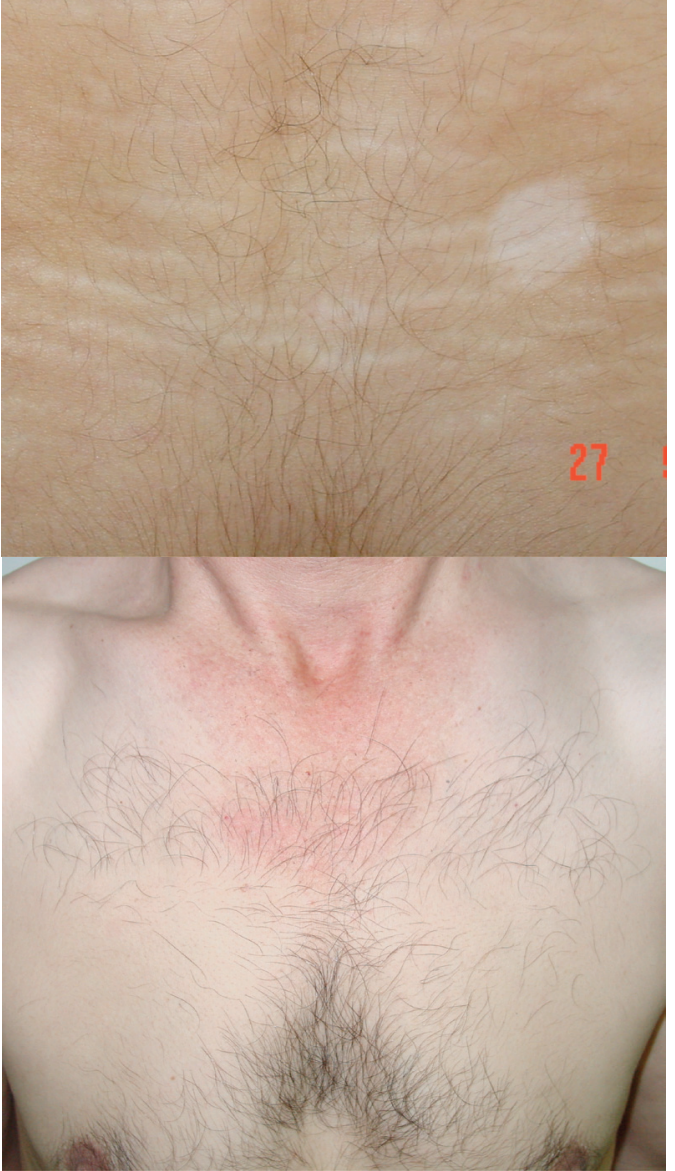

Figure 1. a) Hyperpigmented lesion over the shoulder of patient 1, b) Hairy patch and depigmented lesion over the lower back of patient 4, c) Hairy patch over the anterior thoracic wall of patient 7

\section{Patients 4 and 5}

These two were brothers, both having gingival hyperplasia and odontogenic cysts. The elder brother, who was 19 years old, had milimetric calcifications on the anterior part of falx cerebri, as demonstrated by cranial tomography. His head circumference was $55 \mathrm{~cm}$ ( $25^{\text {th }}-50^{\text {th }}$ percentile), his weight was $63 \mathrm{~kg}\left(10^{\text {th }}-25^{\text {th }}\right.$ percentile $)$ and his height was 180 $\mathrm{cm}\left(75^{\text {th }}-90^{\text {th }}\right.$ percentile). He had palmar pits and atrophic depigmented skin lesions over the back, the forearms and the lower limbs. He also had a hairy patch over his lower back (Figure $1 \mathrm{~b}$ ).

The 15-year-old younger brother had similarly located depigmented lesions as well; however, he did not have palmar pits. In cranial tomography, he was seen to have diffuse calvarial thickening. His head circumference was 53 $\mathrm{cm}\left(25^{\text {th }}-50^{\text {th }}\right.$ percentile), body weight was $57 \mathrm{~kg}\left(25^{\text {th }}-50^{\text {th }}\right.$ percentile), and height was $173 \mathrm{~cm}\left(75^{\text {th }}-90^{\text {th }}\right.$ percentile). He was mildly retarded and unable to read. The karyotype was 47, XXY.

\section{Patient 6}

The sixth patient was an 18-year-old male who had undergone surgery several times for mandibular and maxillary odontogenic keratocysts. When he was two years old, hydrocephalus had been diagnosed. On physical examination, he had macrocephaly (head circumference was $59.5 \mathrm{~cm}$ ), coarse facies with prominent supraorbital ridges and very thick eyebrows, synophrys, a prominent nose with a high nasal bridge, down-slanting and wide palpebral fissures, generalized skin hyperpigmentation with a single $3 \times 3-\mathrm{cm}$ area of hyperpigmentation on the back, and mild prognathism. He weighed $60 \mathrm{~kg}\left(10^{\text {th }}-25^{\text {th }}\right.$ percentiles $)$ and was $179.5 \mathrm{~cm}$ tall $\left(75^{\text {th }}-90^{\text {th }}\right.$ percentiles). Echocardiographic examination showed floppiness of the mitral valve, mild tricuspid regurgitation and mild pulmonary hypertension. Ophthalmologic examination and renal ultrasonography gave normal results. Chromosome analysis was not done.

\section{Patient 7}

The seventh patient was a 47-year-old man operated on several times for odontogenic keratocysts in mandibular and maxillary alveolar processes. He had undergone surgery five times for the excision of facial skin lesions which were histologically diagnosed as basal cell carcinomas. On physical examination, his head circumference was $58.7 \mathrm{~cm}$ (over $97^{\text {th }}$ percentile), he had a coarse face with prominent supraorbital ridges and thick eyebrows, maxillary hypoplasia and prognathism, hyperpigmented and hypopigmented lesions over the scalp and the back, palmar pits and patches of hair over the anterior thoracic wall (Figure 1c). An anteroposterior cranial radiogram showed calcification of falx. Spontaneous sister chromatid exchange was increased, when analysed as previously described (9). 


\section{Patients 8 and 9}

These two patients were a father and daughter. The 42-year-old father had been operated on three times for odontogenic keratocysts. His head circumference was $61 \mathrm{~cm}$ (over $97^{\text {th }}$ percentile), his weight $82.5 \mathrm{~kg}\left(90^{\text {th }}-97^{\text {th }}\right.$ percentiles), and his height was $168 \mathrm{~cm}\left(10^{\text {th }}-25^{\text {th }}\right.$ percentiles). He had a coarse facial appearance with thick eyebrows and prominent supraorbital ridges, a patch of hair over the chest, pectus carinatum, palmar pits and generalized hyperpigmentation. His karyotype was 46,XY and there was no increase in sister chromatid exchanges.

His 13-year-old daughter was born $4500 \mathrm{gr}$ at term, and she developed normally until 5 months of age when she contracted meningitis. Then she had bilateral deafness and severe developmental delay. She presented with left mandibular swelling at the age of 13 when a diagnosis of odontogenic keratocyst was made. Her head circumference was $54 \mathrm{~cm}$ ( $50^{\text {th }}$ percentile), weight $55 \mathrm{~kg}$ ( $75^{\text {th }}$ percentile), and height was $158 \mathrm{~cm}\left(50^{\text {th }}-75^{\text {th }}\right.$ percentiles). She had coarse facies with prominent supraorbital ridges and thick eyebrows, and a high palate. She also had an asymmetry of the thorax and palmar pits. There was a post-axial polydactyly on the right hand. She had no pigmentary abnormalities. Her karyotype was $46, \mathrm{XX}$ with no increase in sister chromatid exchanges.

\section{Patients 10 and 11}

The last two patients were a father and son. The 17-yearold son had received surgery 4 times for odontogenic keratocysts of the jaw. On physical examination, his head circumference was $58 \mathrm{~cm}$ (over $97^{\text {th }}$ percentile), he was 168 $\mathrm{cm}$ tall $\left(10^{\text {th }}-25^{\text {th }}\right.$ percentiles $)$, and weighed $75 \mathrm{~kg}\left(75^{\text {th }}-90^{\text {th }}\right.$ percentile). He had a coarse face with thick eyebrows, and there were several palmar pits bilaterally. Posteroanterior cranial radiogram demonstrated calcification of falx cerebri.

His 51-year-old father had hairy patches over the anterior thorax and a few palmar pits. However, he did not have any history regarding the presence of odontogenic keratocysts and basal cell carcinomas. His head circumference was 59 $\mathrm{cm}$ (50 ${ }^{\text {th }}$ percentile). Calcification of falx cerebri was absent. He was considered to have Gorlin syndrome as his son was affected.

\section{Discussion}

Gorlin syndrome is an autosomal dominant disorder characterized by multiple basal cell carcinomas, jaw keratocysts and skeletal malformations (2). Soft tissue calcifications and dyskeratotic palmar/plantar pits are frequent features (3). The patients may be affected by various types of cancers including medulloblastoma, ovarian fibroma and fibrosarcoma, meningioma, rhabdomyoma, and cardiac fibroma (3).

The presence of the hairy patches is a recenty recognized feature of the syndrome (10). This feature was present in patient 7 and patient 8 , who had the full-blown presentation of the disease. Patient 7 and patient 2, who were 47 and 31 years old respectively, had basal cell carcinomas. The remaining patients who were younger, did not have basal carcinoma which generally arise in older ages. All the patients, except patient 3 who was very young, were referred by dentists after the detection of odontogenic keratocysts, no patient was referred due to basal cell carcinoma. We believe that earlier onset for the odontogenic cysts is an important factor for diagnosis. However, considering the variability in the clinical presentation of Gorlin syndrome, physicians taking care of basal cell carcinomas, including surgeons, dermatologists and dermatopathologists, should be highly prudent in looking for other features of the syndrome. We suggest that generalized hyperpigmentation and/or localized hypo/hyperpigmented areas, which were present in all the patients in our series, may be common features of the syndrome.

The mutated gene in Gorlin syndrome is called PTCH and lies at $9 q 22.3$ (11). Several patients with deletions involving this region have been reported (4-7). Co-occurrence of the condition with Klinefelter syndrome and $(X ; 11)$ translocation in our patients was considered coincidental.

Gorlin syndrome has been suspected as a chromosome instability syndrome. An early study in 1985 (12) showed that there were higher spontaneous and mitomycin-C induced sister chromatid exchange rates in nine Gorlin syndrome patients than in controls. A second study in 1987 showed that the frequency of spontaneous sister chromatid exchange was high in three patients with Gorlin syndrome. Later studies showed no evidence of chromosomal instability compared to controls, when both spontaneous and induced chromosomal breaks were considered (13-16). However, one study involving seven patients in 1995 confirmed the disease as being a chromosome instability syndrome, though spontaneous chromatid breaks occurred more frequently in a subset of patients, indicating a variable expression of this feature (17). In the present series, six of the patients were checked for increased sister chromatid exchange via UV exposure. None showed an increase in the number of sister chromatid exchanges. We were unable to perform sister chromatid exchange analysis in the other patients. Fibroblasts were not tested, since lymphocytes would be appropriately representative of somatic UV susceptibility for DNA breakages. Increased sister chromatid exchanges might be associated with acquired chromosomal abnormalities, both in tissues affected by carcinogenesis and in those without cancer (1). In our cohort, two patients had chromosomal rearrangements; one was a balanced translocation in mosaic and the other was a constitutional aberration, 47,XXY. These two were considered unrelated to a possible UV susceptibility for increased DNA breakages.

Patients with Gorlin syndrome should receive counselling on certain important issues. One is that the disease is inherited in an autosomal dominant fashion, and the future generations may be affected with a $50 \%$ probability. The 
disease is mostly inherited from a parent but may be sporadic in one-fifth. Therefore, parents, siblings and offsprings should be evaluated accordingly. Another point is that all those with consistent findings should be followed-up for carcinogenesis. One major preventive approach is avoiding sunlight exposure. Another should include prudent follow-up after cranial or spinal radiotherapy for medulloblastoma, since sunlight and radiotherapy may be provocative for the development of basal cell carcinomas of the exposed skin (3).

\section{Study Limitations}

Sister chromatid exchange analysis was not done in all of the patients. Testing fibroblasts would also be further informative, since lymphocytes would be appropriately representative of somatic UV susceptibility for DNA breakages.

\section{Conclusion}

Gorlin syndrome is a clinically heterogeneous condition. We conclude that the detection of odontogenic keratocysts and basal cell carcinomas should raise the suspicion of Gorlin syndrome, and the patients should be examined for other clinical findings. Presence of hairy skin patches and pigmentary skin lesions represent the recently recognized physical signs of the disease. Although evidence for chromosome instability was not found in our patients, occurrence of chromosome instability in a subgroup of patients, and mechanisms underlying cancer predisposition require further studies for full elucidation.

\section{Ethics}

Ethics Committee Approval: The study was approved by Hacettepe University Non-Interventional Clinical Research Ethics Board.

Informed Consent: Consent form was filled out by all participants.

Peer-review: External and internal peer-reviewed.

\section{Authorship Contributions}

Surgical and Medical Practices: G.E.U., Y.A., K.B., E.T., Concept: G.E.U, D.A., Design: G.E.U., D.A., Data Collection or Processing: G.E.U., D.A., M.A., Analysis or Interpretation: G.E.U., Y.A., D.A., M.A., K.B., E.T., Literature Search: G.E.U., Writing: G.E.U.

Conflict of Interest: No conflict of interest was declared by the authors.

Financial Disclosure: The authors declared that this study received no financial support.

\section{References}

1. Shafei-Benaissa E, Savage JR, Babin P, et al. The naevoid basalcell carcinoma syndrome (Gorlin syndrome) is a chromosomal instability syndrome. Mutat Res 1998;397:287-92.

2. Gorlin RJ, Goltz RW. Multiple nevoid basal-cell epithelioma, jaw cysts, bifid rib: A syndrome. N Engl J Med 1960;262:908-11.

3. Manfredi M, Vescovi P, Bonanini M, Porter S. Nevoid basal cell carcinoma syndrome: a review of the literature. Int J Oral Maxillofac Surg 2004;33:117-24.

4. Boonen SE, Stahl D, Kreiborg S, et al. Delineation of an Interstitial 9q22 deletion in basal cell nevus syndrome. Am J Med Genet A 2005;132:324-8.

5. Chen $C P$, Lin SP, Wang $T H$, Chen $Y J$, Chen $M$, Wang $W$. Perinatal findings and molecular cytogenetic analyses of de novo interstitial deletion of $9 \mathrm{q}(9 \mathrm{q} 22.3 \mathrm{q} 31.3)$ associated with Gorlin syndrome. Prenat Diagn 2006;26:725-9.

6. Haniffa MA, Leech SN, Lynch SA, Simpson NB. NBCCS secondary to an interstitial chromosome 9q deletion. Clin Exp Dermatol 2004;29:542-4.

7. Shimkets R, Gailani MR, Siu VM, et al. Molecular analysis of chromosome $9 \mathrm{q}$ deletions in two Gorlin syndrome patients. Am J Hum Genet 1996;59:417-22.

8. Gailani MR, Bale AE. Developmental genes and cancer: role of patched in basal cell carcinoma of the skin. J Natl Cancer Inst 1997;89:1103-9.

9. Goto K, Maeda S, Kano Y, Sugiyama T. Factors involved in differential Giemsa-staining of sister chromatids. Chromosoma 1978;66:351-9

10. Wilson LC, Ajayi-Obe E, Bernhard B, Maas SM. Patched mutations and hairy skin patches: a new sign in Gorlin syndrome. Am J Med Genet Part A 2006;140:2625-30.

11. Farndon PA, Del Mastro RG, Evans DG, Kilpatrick MW. Location of gene for Gorlin syndrome. Lancet 1992;339:581-2.

12. Römke C, Gödde-Salz E, Grote W. Investigations of chromosomal stability in the Gorlin-Goltz syndrome. Arch Dermatol Res 1985:277:370-2.

13. Sarto F, Mazzotti D, Tomanin R, Corsi GC, Peserico A. No evidence of chromosomal instability in nevoid basal-cell carcinoma syndrome. Mutat Res 1989;225:21-6.

14. Shafei-Benaissa $E$, Huret JL, Larregue $M$, et al. Checks for chromosomal instability in Gorlin and non-Gorlin basal cell carcinoma patients. Mutat Res 1994;308:1-9.

15. Bale AE, Bale SJ, Murli $H$, Ivett J, Mulvihill JJ, Parry DM. Sister chromatid exchange and chromosome fragility in the nevoid basal cell carcinoma syndrome. Cancer Genetics and Cytogenetics 1989;42:273-9.

16. Stefanini M, Lagomarsini $P$, Berardesca $E$, Borroni $G$, Rabbiosi G, Nuzzo F. Normal sensitivity to mutagens, spontaneous chromosome breakage and mutation frequency in nevoid basal cell carcinoma syndrome. Arch Dermatol Res 1988;280(Suppl):19-23.

17. Shafei-Benaissa E, Savage JR, Papworth D, et al. Evidence of chromosomal instability in the lymphocytes of Gorlin basal cell carcinoma patients. Mutat Res 1995;332:27-32. 